\title{
Conversation Topics on Contact Situation in Introductory Conversations Between Indonesian and Native Japanese Language Speakers A Survey Study on Indonesian Japanese-Language Speakers
}

\author{
Sonda Sanjaya ${ }^{1, *}$ \\ ${ }^{1}$ Japanese Language and Culture Research, Graduate School of Language and Culture, Osaka University \\ Japanese Language Education Department, Universitas Muhammadiyah Yogyakarta \\ *Email:u280314@ecs.osaka-u.ac.jp \\ Email: sonda.sanjaya@umy.ac.id
}

\begin{abstract}
Conversations between speaking partners from different cultures, such as Indonesian and native Japanese language speakers, may include many different topics. However, due to the differences in cultural values between the speakers, the Indonesian Japanese language speakers may speak with a topic that might intrude upon the native Japanese language speakers' privacy, not knowing sensitive topics. This issue may cause a misunderstanding between the speakers. This survey study aims to identify what conversation topics the Indonesian Japanese language speakers may speak to native Japanese speakers in an introductory conversation on the first meeting. An open-ended questionnaire was distributed to 73 students of the Japanese Language Education Department at Universitas Muhammadiyah Yogyakarta to collect the data. The questionnaire included questions on conversation topics that an Indonesian student would like to discuss with Japanese students in five different situations, namely conversations in a cultural exchange event, conversations in Indonesian tourism spots, conversations in Japanese education fairs in Indonesia, conversations in Japanese cultural fairs in Indonesia, and conversations in Indonesian public transportation. Additionally, a follow-up interview to gather detailed answers was conducted with 14 students based on the questionnaire. The survey results showed that Indonesian students wished to discuss personal topics with Japanese students. Therefore, Indonesian students had a high chance of being misunderstood when communicating with Japanese students because they would consider the topic they have chosen to intrude on their privacy. However, as not all personal information is considered privacy-intruding, future survey studies on the Japanese students are necessary to identify private topics.
\end{abstract}

Keywords: Conversation Topics, Privacy, Indonesian Students, Introductory Conversations

\section{INTRODUCTION}

Communication is inseparable from everyday life. For communication to work well, especially during a limited time on the first meeting, speakers need the right conversation topic. For example, an introductory meeting may happen upon an invitation to speak with someone sitting next to you in the airport departure lounge while waiting for departure time. In this situation, how should communication be established, especially if the speech partner has a different cultural background?

Culture and communication are closely related. Culture affects communication, and communication affects the form of culture [1]. Thus, intercultural understanding is essential to establish communication when the speakers come from different cultural backgrounds.
In terms of intercultural communication, topic selection is an essential issue-for example, a conversation between native Indonesian speakers and native Japanese speakers. Mimaki (2018) stated that if the speakers have the same culture, they will share similar understanding regarding what topics of conversation are appropriate and what topics should be avoided in introductory conversations, which are conversations occurring at the first meeting between speakers speech partners [2]. However, the researcher argues that if an introductory conversation occurs between native Indonesian Japanese and native Japanese language speakers, they may not share a similar understanding of what topics of conversation are appropriate and should be avoided.

Besides, the discussion topic must be adjusted to the gender, sexual identity, ethnicity, citizenship, and position of the speakers and speech partners [3]. If the topic of conversation fits these points, then the chances of 
communication success will be high. Whether or not the topic of conversation that will be discussed concerns the privacy of the speech partner is an aspect to consider because there are many cases in which Indonesian speakers discuss a general topic among them, but it is considered private by native Japanese language speakers.

The inaccuracy of the topic may intrude on the speech partner's privacy and cause misunderstanding. According to Gass \& Varonis in Gudykunst \& Kim (1992), communication problems are related to pronunciation, grammar, topic familiarity, intimacy with others, language depth with others, fluency in other languages, and social factors. Therefore, mastering the strategy of selecting conversational topics during communication is crucial [4].

Speakers must avoid various topics, especially topics related to the speech partner's privacy and choose the conversation topic to make the conversation run smoothly. If the conversation goes well because the proper topic is chosen, it is likely to develop a trusting relationship. However, the definition of privacy should be understood. Privacy is matters relating to personal affairs, private life, and secrets [5]. Privacy controls the confidentiality and access to information that a person must not disturb [6]. The realm of privacy is cultural [7]. In other words, what is private differs depending on the original culture.

\section{RELATED RESEARCH}

Sanjaya \& Kusnendar (2018) conducted a study that compared the choice of conversation topics for Japanese speakers who are considered workers (shakaijin) and Indonesian speakers who were considered workers with surveys through closed questionnaires [8]. This research found that these native Indonesian speakers always asked names as the conversation topic with their speech partners. These speakers also often asked where they lived and came from as the topics. Sometimes, they would ask about home addresses, hobbies, work status, and family to their speech partners. Meanwhile, the conversation topics often raised by native Japanese speakers to their speech partners were names. They sometimes asked about hobbies, hometown, weather, holidays, work, the latest news, family, and social media accounts. Judging from the topics raised by the working native Indonesian Japanese speakers, they may offend the native Japanese language speakers' privacy because the home address is one of the topics often raised by the native Indonesian speakers with their speech partners in introductory conversations, but the topic of the conversation is considered privacy-intruding by native Japanese speakers.

Sanjaya \& Ando (2017) studied privacy among Japanese students and Indonesian students. The results of the research are shown in Table 1 below [10].

Table 1. Topics that are Considered Private Domain of Japanese Speaking Students and Indonesian Speaking Students

\begin{tabular}{|l|l|c|c|c|c|}
\hline \multicolumn{3}{|c|}{ Japanese Students } & \multicolumn{3}{c|}{ Indonesian Students } \\
\hline & Privacy & $\begin{array}{c}\text { Percentage } \\
\text { of }\end{array}$ & & Privacy & $\begin{array}{c}\text { Percentage } \\
\text { of }\end{array}$ \\
\hline
\end{tabular}

\begin{tabular}{|c|c|c|c|c|c|}
\hline & & $\begin{array}{c}\text { Respondents } \\
(\%)\end{array}$ & & & $\begin{array}{c}\text { Respondents } \\
(\%)\end{array}$ \\
\hline 1 & $\begin{array}{c}\text { Home } \\
\text { address }\end{array}$ & 78.50 & 1 & $\begin{array}{c}\text { Private } \\
\text { room }\end{array}$ & 58.27 \\
\hline 2 & GPA/Grades & 77.57 & 2 & $\begin{array}{c}\text { Part-time } \\
\text { work salary }\end{array}$ & 55.91 \\
\hline 3 & $\begin{array}{c}\text { Occupation } \\
\text { of family } \\
\text { members }\end{array}$ & 66.36 & 3 & $\begin{array}{l}\text { Significant } \\
\text { other }\end{array}$ & 54.33 \\
\hline 4 & $\begin{array}{c}\text { Private } \\
\text { room }\end{array}$ & 65.42 & 4 & $\begin{array}{l}\text { Occupation } \\
\text { of family } \\
\text { members }\end{array}$ & 48.82 \\
\hline 5 & $\begin{array}{l}\text { Contents of } \\
\text { their } \\
\text { garbage bin }\end{array}$ & 62.62 & 5 & GPA/Grades & 48.03 \\
\hline 6 & $\begin{array}{l}\text { Family } \\
\text { members }\end{array}$ & 55.14 & 6 & $\begin{array}{c}\text { Home } \\
\text { address }\end{array}$ & 26.77 \\
\hline 7 & Birthday & 53.27 & 7 & Birthday & 23.62 \\
\hline 8 & Name & 48.60 & 8 & $\begin{array}{l}\text { Contents of } \\
\text { their } \\
\text { garbage bin }\end{array}$ & 23.62 \\
\hline 9 & $\begin{array}{c}\text { Significant } \\
\text { other }\end{array}$ & 43.93 & 9 & $\begin{array}{c}\text { Family } \\
\text { members }\end{array}$ & 17.32 \\
\hline 10 & $\begin{array}{l}\text { How they } \\
\text { spend } \\
\text { vacations }\end{array}$ & 35.51 & 10 & $\begin{array}{l}\text { Part-time } \\
\text { work }\end{array}$ & 17.32 \\
\hline 11 & $\begin{array}{l}\text { Part-time } \\
\text { work salary }\end{array}$ & 33.64 & 11 & Hobby & 9.45 \\
\hline 12 & $\begin{array}{l}\text { Part-time } \\
\text { work }\end{array}$ & 29.91 & 12 & Name & 8.66 \\
\hline 13 & Hobby & 26.17 & 13 & $\begin{array}{l}\text { How they } \\
\text { spend } \\
\text { vacations }\end{array}$ & 8.66 \\
\hline
\end{tabular}

Sanjaya \& Ando (2017)

Based on Table 1, what is considered private by Japanese students and Indonesian students differs. More than half of the topics considered private for Japanese students are often asked. The Japanese students consider their home address, GPA / grades, family work, room, contents of trash cans, family members, and birth date as private topics. Compared to the Japanese students, as a whole, Indonesian students have a lower percentage, and the private topics considered by Japanese students are only considered private by under $50 \%$ of Indonesian students, including family members, contents of trash, date of birth, home address, GPA / grades, and occupation. From these results, private topics for Japanese students are not considered private by Indonesian students. Students who speak Indonesian can offend Japanese students' privacy.

There are several examples of previous research on privacy, such as the research conducted by Sanjaya \& Ando (2017) and Sanjaya Kusnendar (2018). Both of these studies are studies of intercultural communication, not linguistics. By knowing the privacy realm of native Japanese speakers, conversations can smoothly run because one can choose the right conversation topics with full consideration. However, since everyone has a different sphere of privacy, which is considered private, someone might not be private for someone else. The researcher argues that native Indonesian speakers can converse fluently with native Japanese speakers even if the Indonesian speakers do not know Japanese speakers' privacy domain. If native Japanese speakers show an expression or gesture indicating a dislike of the topic being discussed, it means their privacy is offended. Thus, when a native Indonesian speaker does not realize the conversation topic is offensive, they should recognize the 
native Japanese speakers' expressions or gestures and consider choosing other topics more carefully.

This survey study is a more extensive study on avoiding addressing Japanese speakers' privacy in linguistic studies. This survey was conducted to further explore Japanese speakers' privacy after considering the research results of Sanjaya \& Ando (2017). The data in Sanjaya \& Ando's research were taken through a closed questionnaire with a set of answers that the researcher considered inadequate, and the research did not explore in what situations the topics of conversation were considered private. Thus, for this preliminary survey, the researcher gathered data through open questionnaires and follow-up interviews to determine what topics of conversation were raised by Indonesian students during introductory conversations with Japanese students. Then, from the data obtained, the researcher identified any topics related to personal information and studied topics of conversation that were considered private by Japanese speaking students.

\section{RESEARCH METHOD}

The researcher surveyed what topics Indonesian speaking students would like to discuss with Japanese speaking students in introductory conversations to determine which topics were considered private by Japanese speaking students. The researcher used questionnaires and conducted follow-up interviews to obtain more detailed data than previous studies. The following is the survey method that the researcher used.

\subsection{Data Collection through Questionaire}

The questionnaire that the researcher used was an openended questionnaire to find out what topics of conversation Indonesian students wanted to discuss with Japanese students on their first meeting (introductory conversation) in five different situations, as shown below.

As explained above, the questionnaire questions were arranged in five different situations. The five situations' determination was because of the conversation's place and duration influencing the topics discussed. For example, in Situation 1, namely conversations on cultural exchanges, conversations could take a long time, various kinds of conversation topics could be discussed, and there were opportunities to build friendships while in Situation 3, the conversation objectives had been set, the topics discussed were narrower, and even to make a friendship, the topics should be chosen more carefully. Thus, the questionnaire questions were arranged based on the length of the conversation that might occur and the variation of the conditions and situations.

The questionnaire's respondents and the participants for the follow-up were students of the Japanese Language Education Study Program of Universitas Muhammadiyah Yogyakarta for the 2019/2020 Academic Year. A random sampling technique took respondents, and a total of 73 respondents were obtained from all students (level I-level IV).
After the questionnaire data were collected, all the topics obtained from the data were categorized. The categorization process is carried out by dividing the discussion topics into general discussion topics and situational topics. The general discussion topics were further divided into two types, namely topics raised by Indonesian students and Japanese students, and topics only raised by Indonesian students. The categorization of discussion topics will be further discussed in more detail in Section 4.

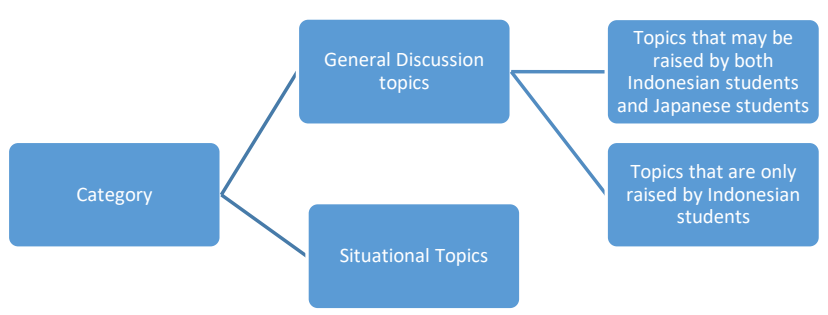

Chart 1 Categorization of Conversation Topics

After the topics of conversation had been categorized, the researcher collected and concluded the types of conversation topics for each situation and their numbers, and at the end, the researchers compared them with the results obtained from the follow-up interviews.

\subsection{Data Gathering through Follow Up Interview on Indonesian Students}

After the data collection through questionnaires was carried out, the researcher conducted a follow-up interview to explore further the answers based on the questionnaire's data analysis. The follow-up interview participants were 14 students from the questionnaire respondents, consisting of two first-year students, four sophomores, four juniors, and four seniors. Follow-up interview questions were the same as in the questionnaire,

\begin{tabular}{|c|c|c|}
\hline Situation 1 & & $\begin{array}{l}\text { Conversations with Japanese students at cultural } \\
\text { exchange events at universities in Indonesia }\end{array}$ \\
\hline Situation 2 & & $\begin{array}{l}\text { Talking to Japanese students or Japanese people } \\
\text { who are approximately } 20 \text { years old at tourist } \\
\text { attractions in Indonesia }\end{array}$ \\
\hline Situation 3 & & $\begin{array}{l}\text { Talking to Japanese students or Japanese people } \\
\text { who are approximately } 20 \text { years old at a Japanese } \\
\text { education fair in Indonesia }\end{array}$ \\
\hline Situation 4 & & $\begin{array}{l}\text { Talking to Japanese students or Japanese people } \\
\text { who are approximately } 20 \text { years old at a Japanese } \\
\text { cultural festival in Indonesia }\end{array}$ \\
\hline Situation 5 & & $\begin{array}{l}\text { Talking to Japanese students or Japanese people } \\
\text { who are approximately } 20 \text { years old who happen } \\
\text { to be sitting next to them on public transportation }\end{array}$ \\
\hline
\end{tabular}

but the researcher tried to get more detail from the answers obtained from the questionnaire by asking questions such as, "Will you continue communication after the introductory conversation with Japanese speaking students is over?" or "Do you intend to make friends after the introductory conversation with Japanese speaking students is over?", "If you intend to make friends with 
them, what topics of conversation or information will you cover?". Data from the follow-up interview were collected and categorized under the same theme as the questionnaire data, along with its frequency

\section{FINDING AND DISCUSSION}

\subsection{Results of the Questionnaire}

Based on the questionnaire results, from all (five) conversation situations, there were 171 topics of conversation that Indonesian Japanese-language speaking students wanted to discuss with native Japanese language speaking students. The results of data categorization, as described in Section 3.1, are shown in Table 2 below.

Table 2. Types of Conversation Topics of Indonesian Speaking Students through a Questionnaire

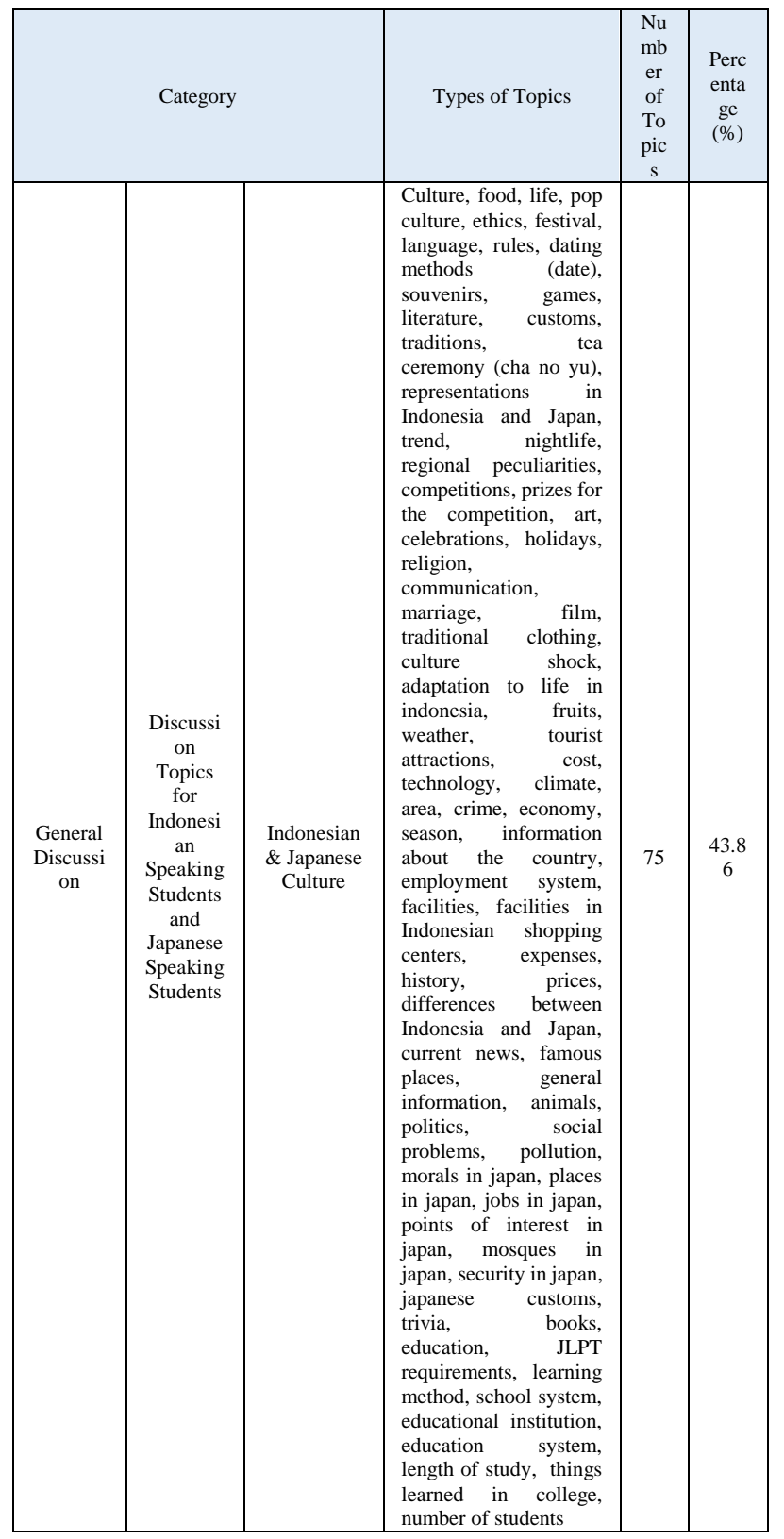

\begin{tabular}{|c|c|c|c|c|}
\hline & $\begin{array}{l}\text { Personal } \\
\text { Information }\end{array}$ & $\begin{array}{l}\text { hometown, daily } \\
\text { activities, work, social } \\
\text { media accounts, } \\
\text { college affiliation, } \\
\text { hobbies, contact } \\
\text { numbers, favorite } \\
\text { things, address in } \\
\text { Indonesia, age, stories } \\
\text { from childhood, } \\
\text { holidays, names, home } \\
\text { addresses, mobile } \\
\text { phone number, } \\
\text { experience, activities in } \\
\text { Indonesia, place of } \\
\text { residence, preferred } \\
\text { places, motivation, how } \\
\text { long they have been in } \\
\text { Indonesia, impressions } \\
\text { about Indonesia, places } \\
\text { they have visited, } \\
\text { opinions about } \\
\text { Indonesia, exchanging } \\
\text { of opinions, impression } \\
\text { of living in Indonesia, } \\
\text { difficulties while living } \\
\text { in Indonesia, the } \\
\text { purpose of coming to } \\
\text { Indonesia, things you } \\
\text { like about Indonesia, } \\
\text { impressions about } \\
\text { Indonesians, } \\
\text { impressions, sources of } \\
\text { knowledge about } \\
\text { Indonesia, how many } \\
\text { times have they been to } \\
\text { Indonesia, the feeling } \\
\text { of wanting to stay in } \\
\text { Indonesia, obstacles } \\
\text { during their stay in } \\
\text { Indonesia, who they } \\
\text { came to Indonesia with, } \\
\text { do they want to stay in } \\
\text { Indonesia, do they want } \\
\text { to come back to } \\
\text { Indonesia, how they } \\
\text { came to Indonesia, their } \\
\text { needs / affairs in } \\
\text { Indonesia, their } \\
\text { roommates Indonesia } \\
\text { In in }\end{array}$ & 41 & $\begin{array}{c}23.9 \\
8\end{array}$ \\
\hline & $\begin{array}{c}\text { Star of the } \\
\text { Conversatio } \\
n\end{array}$ & $\begin{array}{l}\text { self-introduction, } \\
\text { greeting }\end{array}$ & 2 & 1.17 \\
\hline $\begin{array}{l}\text { Discussi } \\
\text { on } \\
\text { Topics } \\
\text { Raised } \\
\text { only by } \\
\text { Indonesi } \\
\text { an } \\
\text { Students }\end{array}$ & $\begin{array}{l}\text { Offers and } \\
\text { Suggestions } \\
\text { from } \\
\text { Indonesian } \\
\text { Speaking } \\
\text { Students }\end{array}$ & 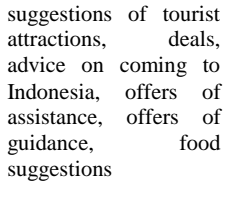 & 6 & 3.51 \\
\hline \multirow[b]{2}{*}{$\begin{array}{c}\text { Situational } \\
\text { Conversation Topics }\end{array}$} & $\begin{array}{c}\text { Tourist } \\
\text { Attractions } \\
\text { in } \\
\text { Indonesia } \\
\text { and Related } \\
\text { Matters }\end{array}$ & $\begin{array}{l}\text { reasons for choosing } \\
\text { Indonesia as a tourist } \\
\text { destination, } \\
\text { impressions about } \\
\text { tourist attractions, } \\
\text { tourist facilities, } \\
\text { reasons for choosing } \\
\text { tourist attraction, the } \\
\text { atmosphere of tourist } \\
\text { attraction, experience } \\
\text { at a tourist attraction }\end{array}$ & 6 & 3.51 \\
\hline & $\begin{array}{l}\text { Matters } \\
\text { related to } \\
\text { Japanese } \\
\text { Education } \\
\quad \text { Fair }\end{array}$ & $\begin{array}{l}\text { examination system, } \\
\text { college, environment } \\
\text { study, lectures, things } \\
\text { to do, university events, } \\
\text { things studied, } \\
\text { references, information } \\
\text { about study in Japan, } \\
\text { study in Japan, barriers } \\
\text { of studying in Japan, } \\
\text { requirements to study } \\
\text { in Japan, scholarship, } \\
\text { college dormitories, } \\
\text { official websites, } \\
\text { student exchange, } \\
\text { internship program, } \\
\text { shops, pamphlets, } \\
\text { stands (booths, } \\
\text { education exhibitions, } \\
\text { booth operating hours, }\end{array}$ & 23 & $\begin{array}{c}13.4 \\
5\end{array}$ \\
\hline
\end{tabular}




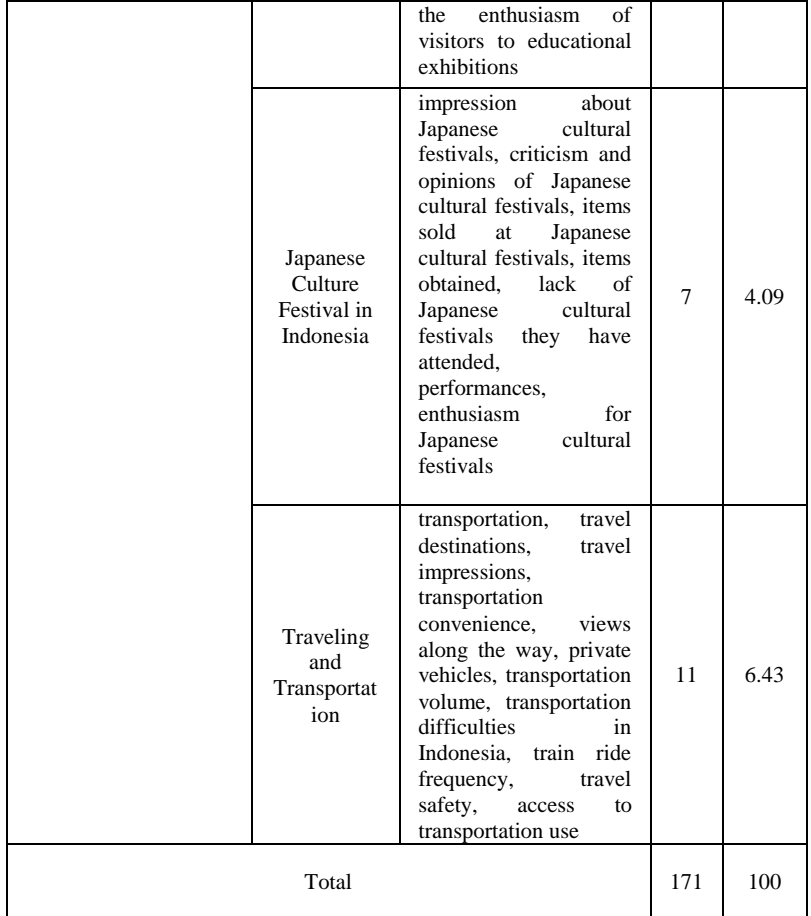

From Table 2, the topics discussed by Indonesian students to Japanese students in the introductory conversation are mainly concerning Indonesian and Japanese culture. Furthermore, the topics that they would like to discuss are topics related to personal information. Unlike the topics of conversation categorized by general topics of conversation, speaking topics categorized based on situational topics of conversation are few. The reason is that the topic is only limited to specific situations, while general topics of conversation are not limited to one situation.

Next, from the category of discussion topics based on general topics of conversation, there are two types of conversation topics, namely topics raised by Indonesian students and Japanese students and topics raised only by Indonesian students. Between the two types, the types of topics of conversation that Indonesian students can raise are very varied (far more than the second type). There are many discussion topics because these topics can be used reciprocally between Indonesian speaking students and Japanese speaking students. The type of topic of conversation that only Indonesian students raise is when the speakers (Indonesian Japanese-language speaking students) themselves offer and give suggestions to their speech partners (native Japanese-language speaking students). For example, when the conversation topic recommends a tourist attraction, Indonesian students can actively talk about it even if the Japanese students do not ask questions about the tourism objects. Other examples include offers for food. In Sundanese and Javanese tribes, it is customary to offer food to other people when they bring food. Therefore, food offers are included in the type of topic of conversation that only Indonesian students raise.

The following are the data analysis results from a questionnaire regarding which respondents most raised categories of conversation topics. The results of the data analysis are shown in Table 3 below.

Table 3. Number of Respondents Based on Conversation Topics from Questionnaires

\begin{tabular}{|c|c|c|c|c|c|c|c|}
\hline \multirow{2}{*}{ Category } & \multicolumn{5}{|c|}{$\begin{array}{l}\text { Number of Respondents in the } \\
\text { Situation }\end{array}$} & \multirow{2}{*}{$\begin{array}{l}\text { To } \\
\text { tal }\end{array}$} & \multirow{2}{*}{$\begin{array}{c}\text { Perce } \\
\text { ntage } \\
(\%)\end{array}$} \\
\hline & 1 & 2 & 3 & 4 & 5 & & \\
\hline $\begin{array}{c}\text { Indonesian and Japanese } \\
\text { Culture }\end{array}$ & $\begin{array}{c}26 \\
2\end{array}$ & 83 & 76 & 98 & 51 & $\begin{array}{c}57 \\
0\end{array}$ & 48.59 \\
\hline Personal information & 45 & 87 & 43 & 62 & 60 & 29 & 25.32 \\
\hline Conversation starter & 10 & 11 & 7 & 17 & 19 & 64 & 5.46 \\
\hline $\begin{array}{l}\text { Offers and Suggestions from } \\
\text { Indonesian students }\end{array}$ & 0 & 8 & 0 & 2 & 1 & 11 & 0.94 \\
\hline Indonesian Tourist Attractions & 0 & 40 & 0 & 3 & 0 & 43 & 3.66 \\
\hline $\begin{array}{l}\text { Things related to Japanese } \\
\text { Education Fairs }\end{array}$ & 0 & 0 & $\begin{array}{c}11 \\
4\end{array}$ & 0 & 0 & $\begin{array}{c}11 \\
4\end{array}$ & 9.71 \\
\hline $\begin{array}{l}\text { Japanese Culture Festivals in } \\
\text { Indonesia }\end{array}$ & 0 & 0 & 0 & 15 & 0 & 15 & 1.28 \\
\hline Trip and Transportation & 4 & 5 & 0 & 0 & 53 & 62 & 5.29 \\
\hline Total & $\begin{array}{c}32 \\
1\end{array}$ & $\begin{array}{c}23 \\
4\end{array}$ & $\begin{array}{c}23 \\
7\end{array}$ & $\begin{array}{c}19 \\
7\end{array}$ & $\begin{array}{c}18 \\
4\end{array}$ & $\begin{array}{l}1,1 \\
73\end{array}$ & 100 \\
\hline
\end{tabular}

Based on the data collected through a questionnaire, Indonesian and Japanese culture's conversation topic is the most discussed. It is because this category has the most varied types of conversation topics raised in any situation. The second-largest category is the personal information category. It appears that there is a considerable gap between these two categories and the other categories. Since the categories of situational topics of discussion are only raised in certain situations, there is a massive difference between the categories compared to the general conversation topics.

\subsection{Results of the Interview}

Next, in this section, the researcher describes the results of the follow-up interview. Discussion topics obtained through follow-up interviews conducted with 14 participants from all questionnaire respondents were categorized as categorizing questionnaire findings. The results of the discussion topic categorization from the follow-up interview findings are shown in Table 4 below.

Table 4. Conversation Topics Gathered from Indonesian Students through Follow-Up Interview

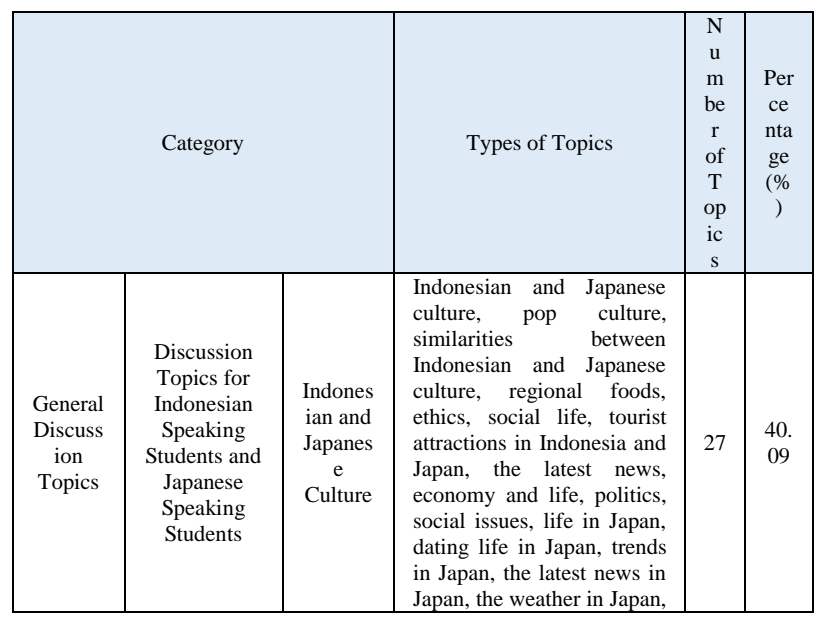




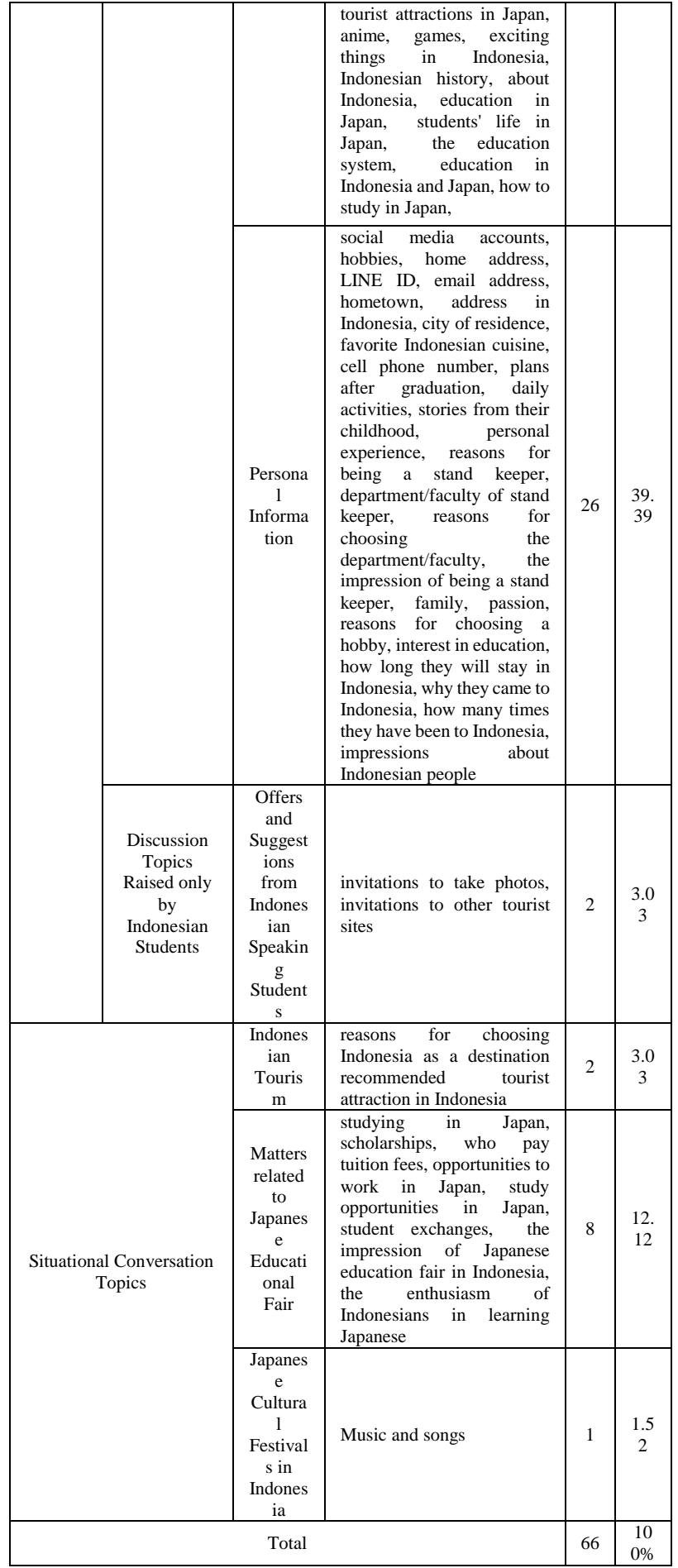

In Table 4, the number of categories and the types of talking topics found from follow-up interviews are less than those found in the questionnaire. The categories included offers, suggestions from Indonesian speaking students, conversation starters, and travel and transportation in the questionnaire result category. However, these categories were not found in the followup interview. On the other hand, the follow-up interviews found the invitation category from students who spoke Indonesian. This finding was obtained because the researcher asked the participants in the follow-up interview about whether they would invite Japanese students to take a photo together or not.

Judging from the number of types of topics of conversation, the category of Indonesian and Japanese culture became the category with the highest number of types of topics of conversation, followed by the category of personal information. Compared to other categories, these two categories are very different in number.

In Table 4, there are topics of conversation, such as a home address, family, cell phone numbers, social media accounts, LINE ID. These topics were founded in Sekizaki (2016) research that showed international students raise topics related to social media (SNS) when conversing with Japanese students at the first meeting in a contact situation [11]. These topics were considered private by Japanese students, although they were not brought up in most situations. These conversation topics can breach Japanesespeaking students' privacy because, based on Sanjaya \& Kusnendar (2018) statement, mobile phone numbers, social media accounts, and email addresses are considered private for working Japanese speakers [8]. The same may be right for Japanese students. Moreover, the follow-up interview results also found sensitive topics of conversation about politics and social issues.

Furthermore, the researcher presented the data analysis results from the follow-up interviews regarding which category of conversation topics the participants raised the most. The results of the data analysis are shown in Table 5 below.

Table 5. Number of Respondents Based on Discussion Topic Categories from Answers to the Follow Up Interview

\begin{tabular}{|c|c|c|c|c|c|c|c|}
\hline \multirow{2}{*}{ Categories } & \multicolumn{5}{|c|}{$\begin{array}{l}\text { Number of Respondents in the } \\
\text { Situation }\end{array}$} & \multirow{2}{*}{$\begin{array}{c}\text { Tot } \\
\text { al }\end{array}$} & \multirow{2}{*}{$\begin{array}{c}\text { Percen } \\
\text { tage } \\
(\%)\end{array}$} \\
\hline & 1 & 2 & 3 & 4 & 5 & & \\
\hline $\begin{array}{l}\text { Indonesian and Japanese } \\
\text { Culture }\end{array}$ & 23 & 11 & 3 & 4 & 3 & 44 & 21.36 \\
\hline Personal Information & 33 & 28 & 32 & 24 & 26 & $\begin{array}{c}14 \\
3\end{array}$ & 69.42 \\
\hline $\begin{array}{c}\text { Invitations from Indonesian } \\
\text { Speakers } \\
\end{array}$ & 0 & 3 & 1 & 0 & 0 & 4 & 1.94 \\
\hline Indonesian Tourism & 0 & 5 & 0 & 0 & 0 & 5 & 2.43 \\
\hline $\begin{array}{c}\text { Matters related to Japanese } \\
\text { Educational Fair }\end{array}$ & 0 & 0 & 9 & 0 & 0 & 9 & 4.37 \\
\hline $\begin{array}{c}\text { Japanese Cultural Festivals } \\
\text { in Indonesia }\end{array}$ & 0 & 0 & 0 & 1 & 0 & 1 & 0.49 \\
\hline Total & 56 & 45 & 46 & 29 & 29 & $\begin{array}{c}20 \\
6\end{array}$ & 100 \\
\hline
\end{tabular}

Table 5 above shows a difference between the results of the follow-up interviews and the questionnaire, namely that in the results of the follow-up interviews, the personal information category is the category of conversation topics raised the most by Indonesian students. However, in Table 4, this category is not the most varied because it is often raised when conversations occur between Indonesian speakers. Then, from the participants' questioning results, they wanted to continue communication using social media after the face-to-face conversation (contact situation) ended and wanted to build deeper relationships. Therefore, Indonesian students would like to talk about social media accounts, LINE ID, 
and email addresses to Japanese students. They were still in the introductory conversation. The second-largest number of topics for discussion is Indonesian and Japanese culture because it is a general topic of conversation and can be discussed in all situations.

From the results of this follow-up interview, Indonesian students have a high probability of intruding upon Japanese students' privacy because they tend to discuss topics of conversation related to Japanese students' personal information in introductory conversations. However, since not all topics of conversation regarding personal information are included in topics of conversation that interfere with Japanese students' privacy, at a later stage, the researcher needed to survey Japanese students to find out what topics of conversation were considered private.

\subsection{Comparison Between Questionnaire Results \\ and Follow-Up Interview Results}

Comparing the results of the questionnaire and the follow-up interview, both show that the category of Japanese and Indonesian culture and the category of personal information are the categories with the most significant number of types of conversation topics. Besides, these two categories have a gap in numbers different from other categories of conversation topics. A comparison of the number of types of discussion topics based on the results of the questionnaire and the results of the follow-up interviews can be seen in Table 6 below

Table 6. Comparison of Questionnaire Results and Follow-Up Interview Results Viewed from the Category of Discussion Topics and the Number of Types of Discussion Topics

\begin{tabular}{|c|c|c|c|c|c|}
\hline \multicolumn{3}{|c|}{ Questionnaire Results } & \multicolumn{3}{|c|}{ Follow Up Interview Results } \\
\hline Category & $\begin{array}{l}\text { Number of } \\
\text { Types of } \\
\text { Conversatio } \\
\text { n Topics }\end{array}$ & $\begin{array}{c}\text { Per } \\
\text { ce } \\
\text { nta } \\
\text { ge } \\
(\% \\
)\end{array}$ & Category & $\begin{array}{c}\text { Number of } \\
\text { Types of } \\
\text { Conversatio } \\
\text { n Topics }\end{array}$ & $\begin{array}{c}\text { Per } \\
\text { ce } \\
\text { nta } \\
\text { ge } \\
(\% \\
)\end{array}$ \\
\hline $\begin{array}{c}\text { Indonesian and } \\
\text { Japanese } \\
\text { Culture }\end{array}$ & 75 & $\begin{array}{l}43 . \\
86\end{array}$ & $\begin{array}{c}\text { Indonesian and } \\
\text { Japanese } \\
\text { Culture }\end{array}$ & 27 & $\begin{array}{l}40 . \\
09\end{array}$ \\
\hline $\begin{array}{c}\text { Personal } \\
\text { Information }\end{array}$ & 41 & $\begin{array}{l}23 . \\
98\end{array}$ & $\begin{array}{c}\text { Personal } \\
\text { Information }\end{array}$ & 26 & $\begin{array}{l}39 . \\
39\end{array}$ \\
\hline $\begin{array}{l}\text { Conversation } \\
\text { Starters }\end{array}$ & 2 & $\begin{array}{c}1.1 \\
7\end{array}$ & & & \\
\hline $\begin{array}{l}\text { Offers and } \\
\text { Suggestions } \\
\text { from } \\
\text { Indonesian } \\
\text { Students }\end{array}$ & 6 & $\begin{array}{c}3.5 \\
1\end{array}$ & $\begin{array}{l}\text { Offers and } \\
\text { Suggestions } \\
\text { from } \\
\text { Indonesian } \\
\text { Students }\end{array}$ & 2 & $\begin{array}{c}3.0 \\
3\end{array}$ \\
\hline $\begin{array}{l}\text { Tourism in } \\
\text { Indonesia }\end{array}$ & 6 & $\begin{array}{c}3.5 \\
1\end{array}$ & $\begin{array}{l}\text { Tourism in } \\
\text { Indonesia }\end{array}$ & 2 & $\begin{array}{c}3.0 \\
3\end{array}$ \\
\hline $\begin{array}{l}\text { Japanese } \\
\text { Education } \\
\text { Fairs }\end{array}$ & 23 & $\begin{array}{l}13 . \\
45\end{array}$ & $\begin{array}{l}\text { Japanese } \\
\text { Education } \\
\text { Fairs }\end{array}$ & 8 & $\begin{array}{l}12 . \\
12\end{array}$ \\
\hline $\begin{array}{c}\text { Japanese } \\
\text { Cultural Fairs } \\
\text { in Indonesia } \\
\end{array}$ & 7 & $\begin{array}{c}4.0 \\
9\end{array}$ & $\begin{array}{c}\text { Japanese } \\
\text { Cultural Fairs } \\
\text { in Indonesia } \\
\end{array}$ & 1 & $\begin{array}{c}1.5 \\
2\end{array}$ \\
\hline $\begin{array}{l}\text { Traveling and } \\
\text { Transportation }\end{array}$ & 11 & $\begin{array}{c}6.4 \\
3\end{array}$ & & & \\
\hline Total & 171 & $\begin{array}{c}10 \\
0\end{array}$ & $100 \%$ & 66 & $\begin{array}{c}10 \\
0 \%\end{array}$ \\
\hline
\end{tabular}

Japanese and Indonesian Culture and personal information are the most discussed categories from the number of discussion topics. However, based on the follow-up interviews, it was clear that topics related to personal information were the topics most Indonesian students used. The number of discussions on the topic was because Indonesian speaking students talked about social media accounts, LINE ID, and email addresses to Japanese students to continue communicating after the introductory conversation to build further relationships. The results of questionnaires and follow-up interviews regarding the many categories of conversation topics that Indonesian students want to discuss with Japanese students can be seen in Table 7 below.

Table 7 Comparison of Questionnaire Results and Follow-Up Interview Results in terms of the Appearance Frequency of Conversation Topic that Indonesian Speaking Students Want to Talk about

\begin{tabular}{|c|c|c|c|c|c|}
\hline \multicolumn{3}{|c|}{ Questionnaire Results } & \multicolumn{3}{|c|}{ Follow Up Interview Results } \\
\hline Category & $\begin{array}{c}\text { Appe } \\
\text { aranc } \\
\text { e } \\
\text { Freq } \\
\text { uenc } \\
\text { y of } \\
\text { Conv } \\
\text { ersati } \\
\text { on } \\
\text { Topi } \\
\text { cs }\end{array}$ & $\begin{array}{c}\text { Perc } \\
\text { enta } \\
\text { ge } \\
(\%)\end{array}$ & Category & $\begin{array}{c}\text { Appe } \\
\text { aranc } \\
\text { e } \\
\text { Freq } \\
\text { uenc } \\
\text { y of } \\
\text { Conv } \\
\text { ersati } \\
\text { on } \\
\text { Topi } \\
\text { cs } \\
\end{array}$ & $\begin{array}{c}\text { Perc } \\
\text { enta } \\
\text { ge } \\
(\%)\end{array}$ \\
\hline $\begin{array}{c}\text { Indonesian and } \\
\text { Japanese Culture }\end{array}$ & 636 & $\begin{array}{c}54.2 \\
2\end{array}$ & $\begin{array}{c}\text { Indonesian and } \\
\text { Japanese Culture }\end{array}$ & 46 & $\begin{array}{c}22.4 \\
4\end{array}$ \\
\hline Personal Information & 297 & $\begin{array}{c}25.3 \\
2\end{array}$ & Personal Information & 140 & $\begin{array}{c}68.2 \\
9\end{array}$ \\
\hline $\begin{array}{c}\text { Conversation } \\
\text { Starters }\end{array}$ & 64 & 5.46 & & & \\
\hline $\begin{array}{c}\text { Offers and } \\
\text { Suggestions from } \\
\text { Indonesian Students }\end{array}$ & 11 & 0.94 & $\begin{array}{c}\text { Offers and } \\
\text { Suggestions from } \\
\text { Indonesian Students }\end{array}$ & 4 & 1.95 \\
\hline $\begin{array}{l}\text { Tourism in } \\
\text { Indonesia }\end{array}$ & 43 & 3.66 & $\begin{array}{l}\text { Tourism in } \\
\text { Indonesia }\end{array}$ & 5 & 2.44 \\
\hline $\begin{array}{c}\text { Japanese Education } \\
\text { Fairs } \\
\end{array}$ & 45 & 3.84 & $\begin{array}{c}\text { Japanese Education } \\
\text { Fairs } \\
\end{array}$ & 9 & 4.39 \\
\hline $\begin{array}{l}\text { Japanese Cultural } \\
\text { Fairs in Indonesia }\end{array}$ & 15 & 1.28 & $\begin{array}{l}\text { Japanese Cultural } \\
\text { Fairs in Indonesia } \\
\end{array}$ & 1 & 0.49 \\
\hline $\begin{array}{c}\text { Traveling and } \\
\text { Transportation } \\
\end{array}$ & 62 & 5.29 & & & \\
\hline Total & 1173 & 100 & $100 \%$ & 205 & 100 \\
\hline
\end{tabular}

\section{CONCLUSION}

From the questionnaires and follow-up interviews, there were many conversation topics that Indonesian speaking students wanted to discuss with Japanese students in introductory conversations, and many of those topics were related to personal information. Students who speak Indonesian are highly likely to cause misunderstandings when having conversations with Japanese students during the introductory conversation by bringing the topics that were considered private by native Japanese language speaking students. However, since not all topics of conversation related to personal information are considered private, future survey studies on topics that could potentially offend privacy considered by native Japanese language speakers are needed. From the next research findings, Japanese learners can know how and what topics should not be chosen and how and what topics 
should be discussed with Japanese speakers in the conversation that occurs at the first encounter.

\section{REFERENCES}

[1] 石井敏・久米照元（2013）『異文化コミュニケーショ ン研究法』東京 : 有斐閣

[2] 三牧陽子（2018）『ポライトネスの談話分析一初 対面コミュニケーションの姿としくみー』東京 : くろしお出 版

[3] Martin, J. N., \& Nakayama, T. K. (2004). Intercultural Communication in Context. New York: McGraw-Hill.

[4] Gudykunst, W. B., Kim, Y. Y. (1992). Communicating with Strangers: An Approach to Inter-cultural Communication. New York: McGrawHill.

[5] Mizutani, Masahiko et al. (2004). The internet and the Japanese conception of privacy. Ethics and Information Technology, 6: 121-128. DOI: https://link.springer.com/article/10.1023/B:ETIN.00 00047479.12986.42

[6] Burgoon, J. K., Parrott, R., Le Poire, B. A., Kelley, D. L., Walther, J. B., \& Perry, D. (1989). Maintaining and restoring privacy through communication in different types of relationships. Journal of Social and Personal Relationships, 6(2),
131-158.

DOI:

https://doi.org/10.1177/026540758900600201

[7] Moore, Adam. (2008). Defining Privacy. Journal of Social Philosophy, 39(3): 411-428. DOI: https://doi.org/10.1111/j.1467-9833.2008.00433.x

[8] Sanjaya, Sonda dan Kusnendar, Muhammad. (2018). Deskripsi Topik Pembicaraan yang Tidak Menyinggung Privasi Bagi Penutur Bahasa Jepang dan Penutur Bahasa Indonesia. Japanese Language Education and Linguistics, 1(2): 199-212. DOI: https://doi.org/10.18196/jjlel.2112

[9] Sanjaya, Sonda dan Yuriko, Ando. (2017) Pandangan Mahasiswa Penutur Bahasa Jepang Terhadap Privasi dalam Komunikasi Ditinjau dari Gender. Japanese Language Education and Linguistics, $\quad 1(1)$ : $1-15 . \quad$ DOI: https://doi.org/10.18196/jjlel.1101

[10] Sanjaya, Sonda dan Yuriko, Ando. (2017) Pandangan Mahasiswa Penutur Bahasa Jepang Terhadap Privasi dalam Komunikasi Ditinjau dari Gender. Japanese Language Education and Linguistics, $1(1)$ : 1-15. $\quad$ DOI: https://doi.org/10.18196/jjlel.1101

[11］関崎博紀（2016）「接触場面初対面会話における 話題スキーマ: 日本の大学における留学生と日本人 学生の会話からの示唆」『筑波大学グローバルコ ミュニケーション教育センター日本語教育論集』31 号 : 17-32 DOI: http://doi.org/10.15068/00137464 